\title{
Micro-morphoanatomical approach for comparative analysis of Tinospora cordifolia (Willd.) Miers and its adulterant plant using SEM and Cryostat
}

\author{
Vidya Shivram Patil' and Nutan Padmnabh Malpathak*2
}

\section{Vidya Shivram Patil ${ }^{1}$ and Nutan Padmnabh Malpathak*2}

1,2Department of Botany, Savitribai Phule Pune University, Ganeshkhind Road, Pune 411007, Maharashtra, INDIA.

\section{Correspondence}

Prof. Nutan P. Malpathak

Email: mpathakster@gmail.com

Ph.no: +91-020-25601439

History

- Submission Date: 01-09-2016;

- Review completed: 10-10-2016;

- Accepted Date: 30-10-2016.

DOI : 10.5530/pj.2017.1.8

Article Available online http://www.phcogj.com/v9/i1

\section{Copyright}

(C) 2016 Phcog.Net. This is an openaccess article distributed under the terms of the Creative Commons Attribution 4.0 International license.

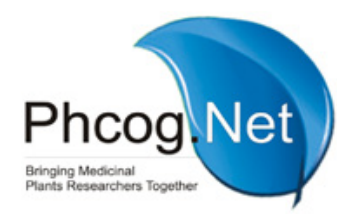

\begin{abstract}
Background: Tinospora cordifolia (Willd.) Miers, belongs to Menispermaceae, commonly known as "Guduchi"or "Amrita" and has immense importance in Ayurvedic medicine. Several studies have been carried out on pharmacology, pharmaceutical, anticancer activity and clinical trials of $T$. cordifolia, however not much information is available on the adulterants that are added with the genuine plant. Considerable work has been done on pharmacognosy but very few studies have been performed on the anatomy of T. cordifolia. Objectives: Comparative micro-morphoanatomical analysis of T. cordifolia and P. daemia, is important for quality control of fresh and dried samples of the root, stem and leaves. Material and Methods: The plant materials of $T$. cordifolia and $P$. daemia were collected, and identified. Fixed sample subjected to cryostat microtomy and sections were observed under light microscope. Micromorphology were studied by light as well as scanning electron microscope. Results: Anatomical studies are cheap and important tool for identification of the correct medicinal plant. Adulterant plant does not contain active principles like Berberine and Tinosporin nor have similar morpho-anatomical characters. Because of the similar appearance and resemblance of dried adulterant plant samples, medicinally important T. cordifolia often get adulterated with other plants. SEM study revealed morpho-anatomical differences like the abundance of starch in cortical and ray parenchyma, different types of trichomes, etc. Cryostat techniques were used for sectioning and showed the presence of xylem plates with wide multicelluar rays. Conclusion: Morphological and anatomical differences were observed in $T$. cordifolia and $P$. daemia. The given results showed significant differences therefore this study aims to help in accurate identification and avoid adulteration of a medicinally important plant.
\end{abstract}

Key words: Tinospora cordifolia, Pergularia daemia, Morpho-anatomy, Berberine, Tinosporin, SEM study.

\section{INTRODUCTION}

Herbal medicine is an important branch of Ayurvedic Medical Sciences; however, there is a lack of standardised identification methods of medicinal plants and bioactive components. Medicinal plants is a subject plagued by multitudes of problems such as incorrect botanical identity, ambiguous local names due to diverse languages, similar morphological characters, active principles, pharmacognosy, and so on.

Tinospora cordifolia (Willd.) Miers belongs to Menispermaceae, has immense importance in Ayurvedic medicine and is commonly known in India as "Guduchi" or "Amrita". The drug obtained from this plant is generally prescribed for fevers, diabetes, dyspepsia, jaundice, urinary problems, skin diseases, chronic diarrhoea and dysentery., "Guduchi-satva", the starch obtained from the stem has high nutritive value and plays an important role in cures to digestive problems and several other ailments. It is also used to treat general weakness, gonorrhoea, secondary syphilis, urinary diseases, impotency, gout, viral hepatitis, skin diseases, and anaemia. In compound formulations, "Guduchi" is used clinically to treat jaundice, rheumatoid arthritis, and diabetes. ${ }^{3}$ The pharmaceutical significance of this plant is mainly because of various bioactive compounds found in this plant such as glucoside, alkaloidal constituents including berberine, three fatty alcohol, a bitter glucoside giloin, a nonglucosidic bitter substance gilonin. ${ }^{4}$ Most recent studies have been focused on phytochemical, pharmacological and clinical investigations. Many interesting findings in the areas of immunomodulation, anticancer activity, liver disorders and hypoglycaemic have been reported. A micromorphoanatomical study would play an important role in preventing adulteration. Despite the number of stud-

Cite this article : Patil VS, Malpathak N. Micro-morphoanatomical approach for comparative analysis of Tinospora cordifolia (Wild.) Miers and its adulterant plant using SEM and Cryostat. Pharmacog J.,2017;9(1):39-45. 
ies carried out on the medicinal importance of T. cordifolia, not much information is available on the adulterants that are added with the genuine plant. Similarly, considerable work has been done on pharmacognosy but there have been very few studies on T. cordifolia. The comparative anatomical study was carried out by Bonde and Upadhye $^{5}$ and according to them $T$. sinensis is often employed in Ayurvedic preparations instead of T. cordifolia. Similarly, histological, histochemical and phytochemical studies carried out by Sereena and Remashree $^{6}$ also revealed the frequent substitution of T. cordifolia with T. sinensis. Use of a plant having the same morphological appearance as an adulterant in place of the medicinally important plant is common place. In the Khandesh region of Maharashtra, many tribals unintentionally use Pergularia daemia plant as adulterant because of the similar morphology and likeness of dried samples. Therefore this study using micro-morphoanatomical analysis is important for quality control of fresh and dried samples of the root stem and leaves of T. cordifolia. Additionally, the present investigation is focused on comparative study of T. cordifolia against its adulterant $P$. daemia, as $T$. sinensis has been studied in depth in the past.

\section{MATERIAL AND METHODS}

The plant materials of T. cordifolia and P. daemia were collected from the campus and Botanical garden of S.S. Ayurved Mahavidyalaya, Hadapsar Pune and M.J. college campus, Jalgaon respectively. Dried materials were submitted to Botanical Survey of India (BSI) Herbarium, Pune for authentication; the corresponding voucher numbers are VP-9 and VP-1. Mature leaves and stem materials were also collected and fixed in FAA for further used. ${ }^{7}$ Suitably trimmed samples were directly embedded in Leica OCT solution. Serial transverse, tangential and radial longitudinal sections of 15-25 $\mu \mathrm{m}$ thickness were obtained with the help of a Cryostat microtome (Leica CM1520). Sections were stained with Safranin-fast green combination ${ }^{7}$ dehydrated through ethanol-xylene series and subsequently mounted in DPX.

For Scanning Electron Microscopic analysis, samples were fixed and dehydrated in an ascending ethanol series ${ }^{9}$ and finally in graded series of alcohol: Isoamyl alcohol. Samples were kept in pure IAA and then sputter coated with gold. The leaf surface was then observed using a Scanning Electron Microscope (JEOL JSM-6360A, Japan) at different magnifications, $100 \mathrm{x}$ to $10000 \mathrm{x}$.

Small pieces of the stem were macerated with Jeffery's solution ${ }^{8}$ at $55^{\circ} \mathrm{C}$ to $60^{\circ} \mathrm{C}$ for $24-38$ hours and stained with $0.5 \%$ aqueous Safranin to obtain the length and width of vessels elements and fibers as well as to study morphology. One hundred readings were taken to obtain the mean and standard deviation. Important results were micro-photographed with a Leica DM 3000 LED research microscope.

\section{RESULTS}

General Morphology: General morphology of Tinospora cordifolia (Willd.) Miers. and adulterant plant Pergulari adaemia (Forssk.) Chiov. are given in Table 1, Figure 1 and Micro-morphology is given in Table 2.

Leaf Anatomy: In all studied species, transverse section of the leaf showed uniseriate epidermis covered with a thin cuticle. It consisted of stomata and trichomes on both, upper and lower surface. SEM study of Tinospora cordifolia leaves showed anomocytic stomata with very few trichomes on the midrib. The trichomes had an elongated globous head (Figures 1C, D). Conversely, paracytic stomata were observed in Pergularia daemia (Figures 1E, F). Epidermis in both was followed by mesophyll tissue with dorsiventral arrangement of one or two stratum of the palisade and three or four layers of spongy tissue (Figures 2B, D). Length and width of the palisade varied between the plant species. They had 30-40 mm length and 12-16 mm width in Tinospora and 40-50 mm length and 07-12 mm width in Pergularia. Cross section of the midrib in Tinospora showed broad hump on the lower side and a slight convex where-as in Pergularia it was convex on the lower side and slightly flat on the upper surface (Figures 2A, B). Tinospora had a single large collateral vascular bundle in the center surrounded by thin parenchymatous cells of the midrib whereas 6-7 in Pergularia. In lamina portion, minor vascular bundles were placed in both the plant species.

\section{Stem Anatomy}

The outer layer was periderm and formation was observed at a very early stage. Periderm was broken as lenticels protruded out breaking the periderm at a number of places in both the plants (Figures 3A, D). Periderm was followed by cortex and was composed of two distinct zones, outer 1 or 2 layered sclerenchymatous and inner parenchymatous 15 to 22 layered in Tinospora.

In Pergularia, starch grains were present in the parenchymatous region abundantly (Figures 3E, F). Endodermis was single layered and followed by pericycle. It was made up of thick-walled cells which formed a cap-like structure on each vascular bundle in Tinospora, while in Pergularia the endodermis and pericycle were inconspicuous (Figures 3A, D). The young stem of Tinospora comprised of 5 to 8 collateral vascular bundles in a ring whereas 5 to 10 in Pergularia, and separated by parenchyma and medullary rays in both plants. A thin layer of cambium was present between the xylem and phloem in young stems of both plants and in mature stem of Tinospora, a single layer of cambium was also present in ray regions which was not shown by Pergularia. In Pergularia, druses were present in phloem parenchyma and cortical parenchyma while in Tinospora stem was characterized by specialized starch grains (Figures 3D,C). In young Tinospora stem, parenchymatous pith with compact cells containing starch grains was present in the center. In both Tinospora and Pergularia, mature stem's periderm and cortex were wide and the periderm peeled off periodically (Figures 3B). Cortex was made up of both parenchymatous and sclerenchymatous tissues. In mature Tinospora stem, the pericyclic sclerenchyma and phloem capping the vascular bundles were fragmented forming a banded structure of secondary xylem which were not observed in Pergularia (Figures 3B D). In Pergularia, druses and secretary canals were present in the cortical region, while in Tinospora it was filled with starch grains and no druses were observed in the cortex.

Fiber tracheids were 600-700 $\mu \mathrm{m} \& 400-780 \mu \mathrm{m}$ in length and $25-30 \mu \mathrm{m}$ $\& 12-25 \mu \mathrm{m}$ in width in Tinospora and Pergularia respectively. In macerated material we observed vessel and fibre structure difference in given species (Figures 2E, F). Vessels were mostly solitary, however radial or tangential multiples of 3-5 vessels were also observed infrequently. Vessels were mostly oval too long in cross section in both the climbers. Vessel dimorphism were prominently observed in Tinospora and vessels were often obstructed by numerous tyloses, which sometimes resulted in complete blockage of the lumen. Such tyloses frequently showed deposition of prominent starch granules (Figures 3C). On the basis of their diameter, vessels could be categorized into wider or narrower vessel elements (Figures 2E, F). The length of the wider vessel elements was less than its diameter. In Tinospora, wide vessels were measured from $165-300 \mu \mathrm{m}$ in length and $270-425 \mu \mathrm{m}$ in diameter while the narrower vessel elements were longer than their diameter, i.e. they were $237-300 \mu \mathrm{m}$ in length and $62-100 \mu \mathrm{m}$ in width. On the other hand, in Pergularia vessels were solitary and measured $135-330 \mu \mathrm{m}$ in length and $45-88 \mu \mathrm{m}$ in width. Comparatively larger vessels were present and vessel dimorphism was seen prominently in Tinospora. Vessels possessed simple perforation plate on their slightly oblique to transverse end walls alternate bordered pits. In Tinospora, wide medullary rays of up to 15-25 cells with alternating 
Malpathak et al.: Micro-morphoanatomical approach for comparative analysis of T. cordifolia \& its adulterant plant using SEM \& Cryostat

\section{Table1: T. cordifolia and P. daemia are differentiated on the basis of following morphological characters}

\begin{tabular}{|c|c|c|}
\hline & Tinospora cordifolia (Willd.) Miers. & Pergularia daemia (Forssk.) Chiov. \\
\hline Habit & Large, glabrous, perennial, deciduous, climber of weak and fleshy stem & $\begin{array}{l}\text { Trellis-vine, fetid- smelling perennial climber, extensive hairy } \\
\text { tomentose }\end{array}$ \\
\hline Leaves & $\begin{array}{c}\text { Simple, glabrous, alternate, exstipulate, membranous, broad ovate to } \\
\text { round, deeply cordate at base }\end{array}$ & Opposite, reniform, ovate, acuminate, glabrous, deeply cordate at base \\
\hline Flowers & $\begin{array}{l}\text { Small, yellow or greenish yellow, terminal racemes/ racemose panicles, } \\
\text { the male flowers are usually clustered and female flowers are solitary }\end{array}$ & $\begin{array}{c}\text { Flowers in drooping corymbose cymes, hairy peduncle, lanceolate } \\
\text { bracts, acute, densely pubescent }\end{array}$ \\
\hline $\begin{array}{l}\text { Calyx \& } \\
\text { Corolla }\end{array}$ & Sepals \& Petals 6 free, smaller than sepals, obovate and membranous. & $\begin{array}{c}\text { Calyx villous, sepals ovate-lanceolate and corolla glabrous outside, hairy } \\
\text { within, dull greenish yellow or white }\end{array}$ \\
\hline Stamens & Stamens 6, free, filaments clavate & Pollinia pendulus, corona double \\
\hline Ovary & 3-6 free carpels, uniovulate mature carpel & 2 carpels, biovulate \\
\hline Fruit & The drupes are ovoid, glossy, succulent, red and pea sized & $\begin{array}{c}\text { Fruits (follicles) lanceolate, long-pointed, about } 5 \mathrm{~cm} \text { long, covered with } \\
\text { soft spines and seeds are pubescent, broadly ovate }\end{array}$ \\
\hline
\end{tabular}

Table 2: Micro-morphology of studied plants

\begin{tabular}{ccc}
\hline Micro-morphology & Tinospora cordifolia (Willd.) Miers. & Pergularia daemia (Forssk.) Chiov. \\
\hline Stomata & Anomocytic & Paracytic \\
Trichome & Trichomes are few only present on vasculature with globous head & Uniseriate multicellular hair \\
Crystals & Starch-grains, Druses (Calcium oxalate crystals) present & Druses are present in phloem region \\
\hline
\end{tabular}

xylem plates were observed. Rays were measured about 1450-2300 $\mu \mathrm{m}$ in height and 300-390 $\mu \mathrm{m}$ in width in Tinospora. In tangential view, they were heterocellular and most of the rays were procumbent while square and upright cells were especially found on the ray periphery (Figures $3 \mathrm{C}$ ). Pergularia lacked such wide rays. In both species, pith was made up of parenchymatous cells and filled with starch grains (Figures 3E, F).

Root Anatomy: In Tinospora, roots were of two types, aerial and underground, while in the case of Pergularia it was normal. The young aerial roots were thin and squarish while mature aerial root was circular. The anatomy of underground root started with a single outer epiblema layer made up of thick-walled cells. This was followed by the cortex composed of an outer layer of parenchymatous and inner sclerenchymatous layers in Tinospora while in Pergularia the outer layer was parenchymatous only. In both studied plants cortex was made up of thin walled, compactly arranged parenchymatous cells containing starch grains. In Tinospora, 5-8 vascular bundles were arranged in a ring while in the case of Pergularia the number was 5-10. Xylem was exarch with large parenchymatous pith in both studied plants.

\section{DISCUSSION}

Both Tinospora and Pergularia have enormous importance in pharmacology. Their species are widely distributed in the tropical and subtropical regions of India and China ${ }^{10-12}$ and have multiple applications in different folk medicine, including the Indian Ayurvedic system. ${ }^{10-13}$ The plant $T$. cordifolia has medicinal properties like anti-diabetic, antipyretic, antispasmodic, anti-inflammatory, anti-arthritic, antioxidant, anti-allergic, anti-stress, anti-leprotic, antimalarial, hepato-protective, immuno-modulatory and anti-neoplastic activities which have been proven by reverse pharmacological approach ${ }^{11}$. While $P$. daemia is used as anti-helminthic, laxative, antipyretic and expectorant, and also used to treat infantile diarrhoea and malarial intermittent fevers, the latex of this plant used as a toothache cure. ${ }^{11,14,15}$ Compared to Pergularia, Tinospora is more commonly used in various preparations of Ayurvedic medicines as various cited references suggest.
There are various studies available on phytochemical, quantitative and qualitative analysis of both plants. ${ }^{4,13,16-18}$ Market samples of Tinospora are often found to be adulterated with other species of Tinospora like T. sinensis. ${ }^{6}$ These adulterated samples lack active principles like Berberine, Tinosporin, Tinocordiside, Tinocordifolioside, Cordioside, Cordifolioside-A, Cordifolioside-B, etc. While Sereena and Remashree, ${ }^{6}$ mentioned that the drug obtained from T. cordifolia was often substituted with $T$. sinensis, no studies were done on adulteration or substitution of $T$. cordifolia with $P$. daemia. Our survey indicated that in some places of Maharashtra, $P$. daemia was frequently used as an adulterant for T. cordifolia because of their morphological similarities.

Comparative morphology and anatomy studies have suggested the characteristic differences between Tinospora and Pergularia, such as the presence of abundant hair on the stem of Pergularia which were not observed in Tinospora. Anatomical differences were 1) plenty of starch grains seen in Tinospora which was not observed in Pergularia, instead druses were observed in the cortex, and 2) the transverse section showed xylem plates and wide rays in Tinospora stem and root which were absent in Pergularia. However, no detailed study has been done on comparative stem and root anatomy of Tinospora and Pergularia.

Metcalfe, Chalk, ${ }^{19}$ reported Rananculaceous (anomocytic) stomata in Menispermaceae, Rubiaceous (paracytic) in Asclapiadaceae. Similarly, present investigation showed similar results which were confirmed by SEM study in greater clarity facilitating accurate identification. Finally, our observations on stomata and trichomes were in agreement with those described by Metcalfe, Chalk. ${ }^{19}$

Anatomical study of $T$. cordifolia has been done by various researchers $^{5,6,19,20}$ but there was no comparative study available on Tinospora and its adulterant. Stem and root anatomy of Tinospora resembled Aristolochia stem which is commonly known for its atypical wood anatomical structure, i.e. lignified xylem plates embedded in parenchymatous ray cells. A similar structure was also observed in some members of Menispermaceae, for example in genera Coscinium, Borismene, Tinomiscium and Penianthus. ${ }^{21}$ Additionally, such structure is not observed in members of Asclepiadaceae; stem cross section of Pergularia did not show xylem 

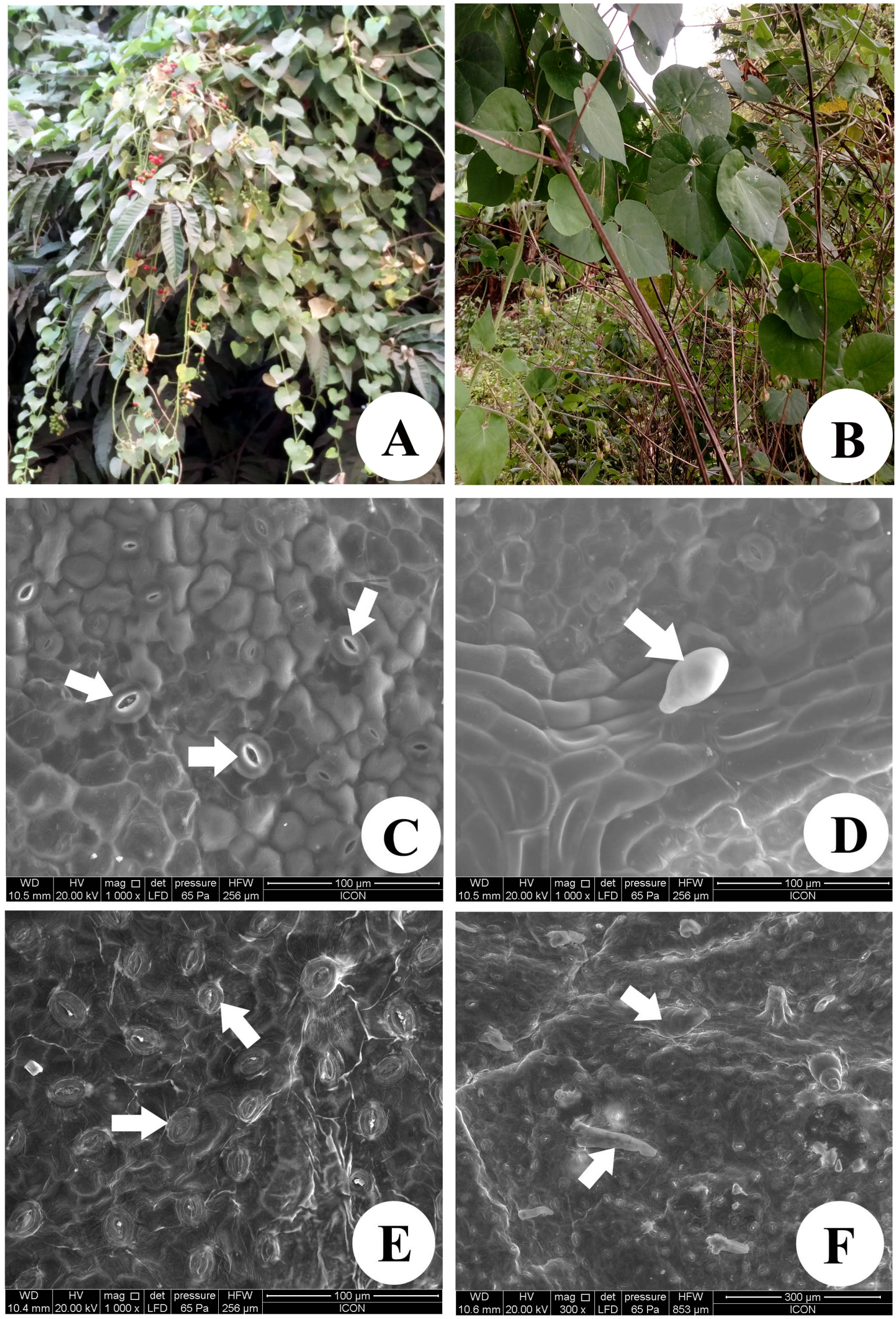

Figure 1: General morphology and scanning Electron microscopy of T. cordifolia and P. daemia 

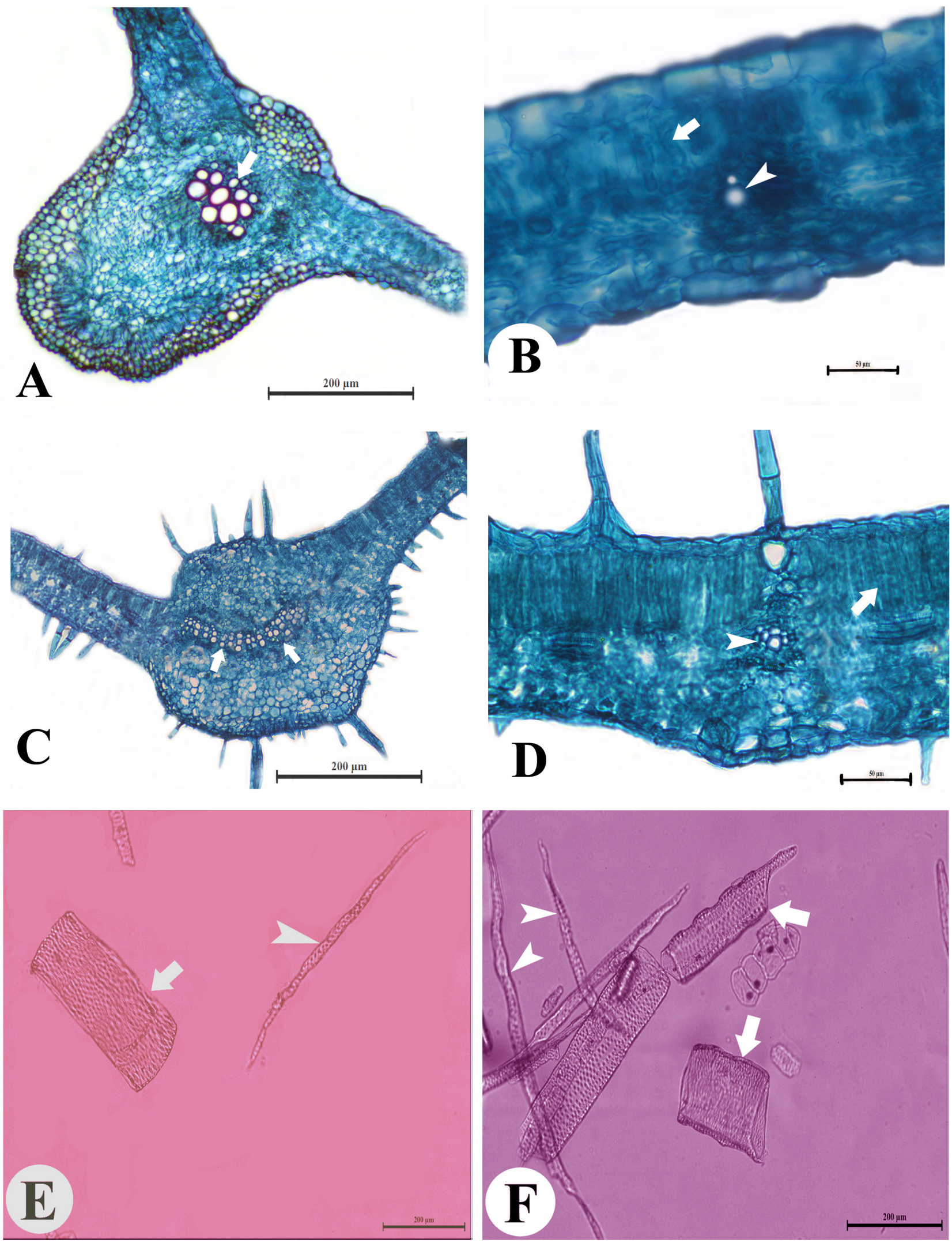

Figure 2: Transverse view of leaf A-D and macerated xylem elements of T. cordifolia and P. daemia 

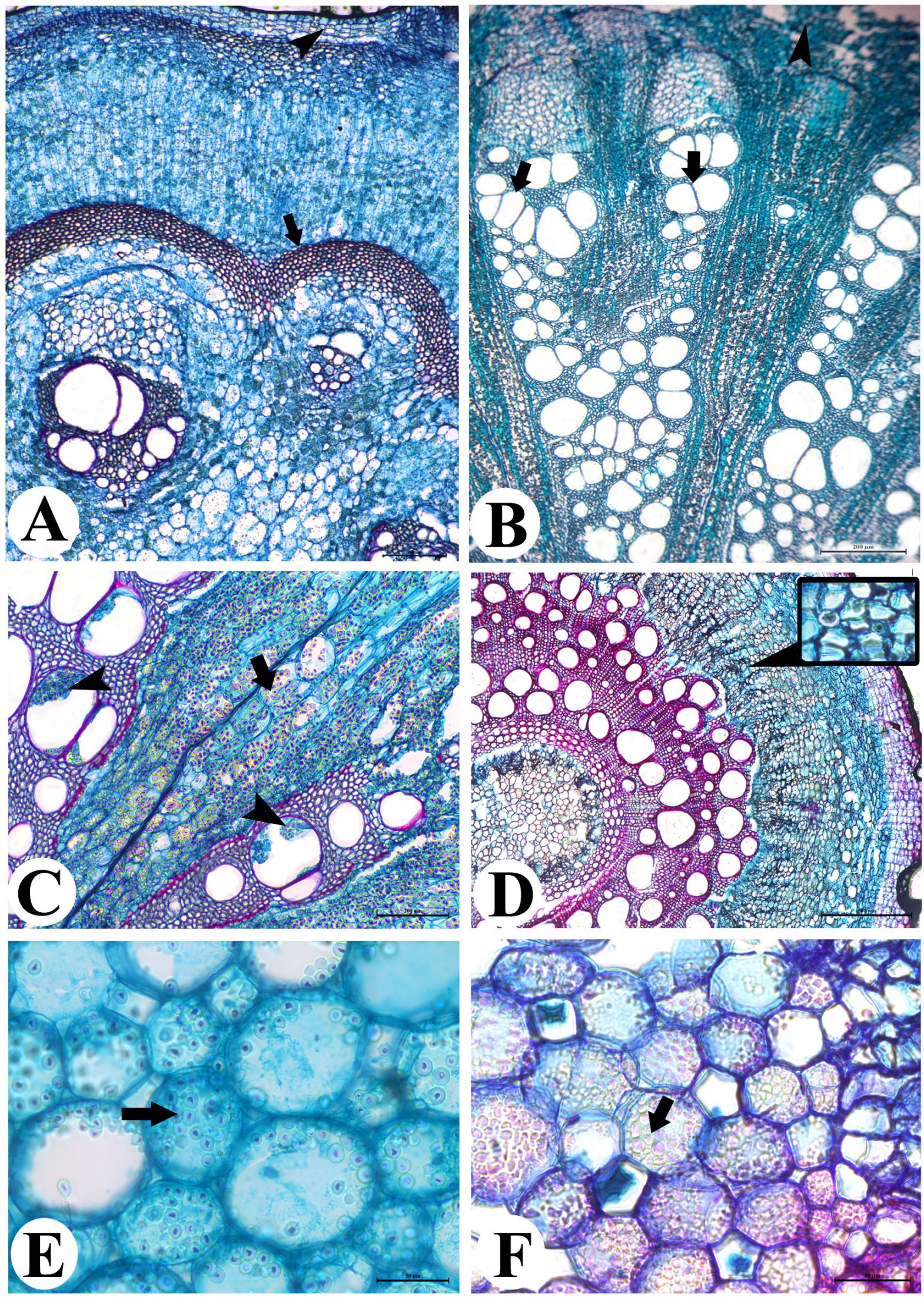

Figure 3: Transverse sections of the stem of T. cordifolia and P. daemia 
plates alternate with wide parenchymatous ray. It is a distinct feature of identification to avoid adulteration. The starch grains in Tinospora were very specific in shape, size and structure, and were numerous when compared to the adulterant plants. Druses were present in the cortical region in Tinospora, while they were present in phloem region of Pergularia. Bonde and Upadhye, ${ }^{5}$ reported that a group of stone cells were present in the cortical region and starch grains in all parenchymatous cells and calcium oxalate crystals were absent in cortex. In all Menispermaceae members, ray cells contained either starch grains or remnants of starch grains. ${ }^{20}$ Our study is also supported by Bonde and Upadhye, ${ }^{5}$ Carlquist ${ }^{20} 1988$ findings.

\section{ACKNOWLEDGEMENT}

The authors are thankful to the Dr. DS Kothari Fellowship program and University Grants Commission, for the financial support.

\section{REFERENCES}

1. Misra B, Bhava Prakash Nighantu Vol. 1 (Hindi commentary by KC Chunekar) Chowkhambavidya bhava, Varanasi, 1969.

2. Sinha K, Mishr NP, Singh J, Khanuja SPS. Tinospora cordifolia; a reservoir pant for therapeutic application. Indian J Traditional Knowledge. 2004;3(3):257-70.

3. Neeraja PV, Margaret E. Amruthavalli: Tinospora cordifolia: Multipurpose rejuvenator. International Journal of Pharmaceutical, Chemical \& Biological Sciences. 2013;3:233-41.

4. Singh SS, Pandey SC, Srivastava S, GuptaVS, Patro B. Chemistry \& medicinal properties of Tinospora cordifolia. Indian Journal of Pharmacology. 2003;35(2):83-91.

5. Bonde SD, Upadhye AS. Contribution to the wood anatomy of Tinospora sinensis (Lour) Merrill in relation with T. cordifolia Miers. Ancient Science of Life. 1987;9(2):80-5

6. Sereena K, Remashree AB. Histological, Histochemical and Phytochemical Studies of The Raw Drug Amrita From Different Raw Drug Markets of Kerala. International Journal of Interdisciplinary and Multidisciplinary Studies. 2014:1(5):182-91.

7. Johansen DA. Plant microtechnique, McGraw Hill NewYork;1940; P.523.

8. Berlyn GP, Miksche JP. Botanical microtechnique and cytochemistry. Ameslowa;
The lowa Unipress; 1976.P.326.

9. Souza W. Técnicas básicas de microscopia eletrônica aplicadas às Ciências Biológicas. Rio de Janeiro: Sociedade Brasileira de Microscopia Eletrônica; 1998;33-44.

10. Golam S, Gafur MA, Shah MAB, Khurshid AHM, Biswas MHU, Hassan P. Antifertility activity of Pergulari adaemia. J Medical Sci. 2001;1:22-4. http:// dx.doi.org/10.3923/jms.2001.22.24.

11. Upadhyay AK, Kumar K, Kumar A, Mishra HS. Tinospora cordifolia (Willd.) Hook. f. and Thoms. (Guduchi) - Validation of the Ayurvedic pharmacology through experimental and clinical studies. Int J Ayurveda Res. 2010;1(2):112-21. http:// dx.doi.org/10.4103/0974-7788.64405; PMid:20814526 PMCid:PMC2924974.

12. Ayyanar M, Ignacimuthu S. Ethnobotanical survey of medicinal plants commonly used by Kanitribals in Tirunelveli hills of Western Ghats, India J. Ethnopharmacol. 2011;134(3):851-64. http://dx.doi.org/10.1016/j.jep.2011.01.029; PMid:21291981.

13. Sutar NG, Pal SC. Finger printing analysis of the flavonoid from leaves Pergulariadaemia Forsk using HPTLC analysis. Journal of Pharmacognosy and Phytochemistry. 2015;3(5):157-61.

14. Wahi AK, Ravi J, Hemalatha S, Singh PN. Antidiabetic activity of Daemia extensa. J Natural Remedies. 2002;2(1):80-3.

15. kumar SSV, Mishra SH. Hepatoprotective activity of extracts from Pergularia daemia (Forsk.) against carbon tetrachloride-induced toxicity in rats. Pharmacog Magazine. 2007;3(11):187-91.

16. Tanwar S, Jain J, Verma S, Solank D. Standardization and phytochemical evaluation of Tinospora cordifolia (Willd.) Miers. (Menispermaceae). International Journal of Pharmacy and Pharmaceutical Sciences. 2012;4:219-23.

17. Dalai S, Meher S, Mahapatra B, Dwivedi L. The quality control assesment of 'Guduchi Satwa': A Traditional Herbal Formulation. Universal Journal of Pharmacy. 2014;3(2):81-7.

18. Shinkafi SA. Phytochemical Analysis and Chromatographic Studies of Pergularia tomentosa L. and Mitracarpusscaber Zucc. British Microbiology Research Journal. 2014;4(5):550-9. http://dx.doi.org/10.9734/BMRJ/2014/3534.

19. Metcalf CR. Chalk L. Anatomy of dicotyledons, Clarendon Press, Oxford; v.2, 1983. 1059-67.

20. Carlquist S. Comparative Wood Anatomy, Systematic Ecological and Evolutionary Aspect of Dicotyledonous Wood. Springer-Verlag, Heidelberg, Berlin, New York; 1988.

21. Jacques FMB, Franceschi D De. Menispermaceae wood anatomy and cambial variants IAWA Journal. 2007;28(2):139-72. http://dx.doi.org/10.1163/2294193290001631.

Cite this article : Patil VS, Malpathak N. Micro-morphoanatomical approach for comparative analysis of Tinospora cordifolia (Wild.) Miers and its adulterant plant using SEM and Cryostat. Pharmacog J.,2017;9(1):39-45. 